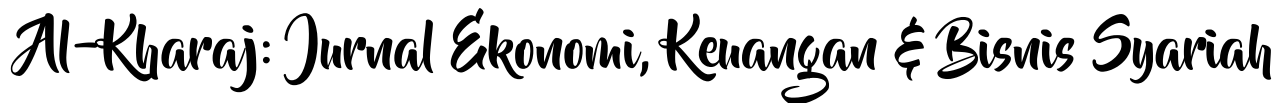

Volume 4 No 4 (2022) 1090-1106 P-ISSN 2656-2871 E-ISSN 2656-4351

DOI: $10.47467 /$ alkharaj.v4i4.840

\section{Implementasi Akad Murabahah Pada BMT Usaha Mulya Masjid Raya Pondok Indah Jakarta}

\author{
Daffa Putra Alvaro, Erlinda Sheila Amanda, Tiara Kirana Prameswari, Falikhatun \\ 1,2,3,4 Universitas Sebelas Maret \\ daffaputraalvaro@gmail.com, erlindasheila@gmail.com, \\ tiara.kirana71@student.uns.ac.id, falie.feuns17@gmail.com
}

\begin{abstract}
This study aims to identify the application of sharia principles that are applied to the BMT Masjid Raya Pondok Indah Jakarta. Nowadays, the problems that develop in the community regarding murabahah contracts, especially those carried out by the BMT, are deviating from sharia principles. This study uses an exploratory research method, namely by using the interview method to obtain data from the BMT of the Pondok Indah Syariah Raya Mosque, Jakarta. The results of this study indicate that in practice, BMT has implemented a murabahah contract in accordance with sharia principles. However, BMT Masjid Raya Pondok Indah Jakarta Sharia encountered obstacles in applying for other funding sources, due to many doubts and difficulties in practice.
\end{abstract}

Keywords: Author Guidelines; Murabahah Contract, Sharia Principle, Baitul Mal Wa Tamwil

\section{ABSTRAK}

Studi ini bertujuan untuk mengidentifikasi penerapan prinsip syariah yang diterapkan pada BMT Masjid Syariah Raya Pondok Indah Jakarta. Dalam dewasa ini, permasalahan yang berkembang di masyarakat mengenai akad murabahah khususnya yang dilakukan oleh pihak BMT yakni menyimpang dari prinsip syariah. Studi ini menggunakan metode exploratory research yakni dengan menggunakan metode wawancara untuk mendapatkan data dari pihak BMT Masjid Syariah Raya Pondok Indah Jakarta. Hasil penelitian ini menunjukan bahwa dalam melakukan prakteknya, BMT sudah menerapkan akad murabahah sesuai dengan prinsip-prinsip syariah. Namun, BMT Masjid Syariah Raya Pondok Indah Jakarta mengalami hambatan dalam menerapkan sumber pendanaan lain, karena banyak keraguan dan kesulitan dalam prakteknya.

Kata kunci: Akad Murabahah, Prinsip Syariah, Baitul Mal Wa Tamwil

\section{PENDAHULUAN}

Pembiayaan murabahah adalah transaksi jual beli di mana bank menyebut jumlah keuntungannya. Bank bertindak sebagai penjual, sementara nasabah sebagai pembeli. Harga jual adalah harga beli bank dari pemasok ditambah keuntungan (marjin). Kata 


\section{Al-Kharaj: Jurnal Ekonomi, Kenangan \& Bisnis Syariah \\ Volume 4 No 4 (2022) 1090-1106 P-ISSN 2656-2871 E-ISSN 2656-4351 DOI: $10.47467 /$ alkharaj.v4i4.840}

murabahah berasal dari kata ribhu yang memiliki arti keuntungan. Pada pembiayaan ini kedua belah pihak harus menyepakati harga jual dan jangka waktu pembayaran. Harga jual yang sudah ditulis dalam akad jual beli dan jika telah disepakati tidak dapat berubah selama berjalannya akad. Akad murabahah terdapat jenis lainnya yaitu pembiayaan murabahah wakalah atau perwakilan.

Pembiayaan murabahah banyak dipilih oleh nasabah untuk melakukan transaksi jual beli karena memiliki beberapa manfaat dibandingkan pembiayaan di bank. Salah satu manfaat yang dirasakan oleh nasabah yaitu kesepakatan margin antara kedua belah pihak ditentukan di awal sehingga pada berjalannya akad tidak terdapat pihak yang merasa dirugikan.

Pertumbuhan bank atau lembaga keuangan syariah Indonesia saat ini sangat cepat dengan meningkatnya pemahaman masyarakat tentang riba (Bunga) dan hasil pokok sudah ditentukan sebelumnya. Baitul maal wa tamwil (BMT) sesuai dengan prinsip syariat, semua transaksi Apa yang dilakukan harus berdasarkan prinsip syariah. Artinya semua kontrak dianggap sah, jika Kontrak memenuhi persyaratan pilar, tetapi jika tidak, transaksi tidak valid (Huda,2018). Tentu saja, untuk kegiatan jual beli, Anda perlu membuat kontrak yang jelas. Hal ini karena jika akad dilaksanakan secara tidak benar, maka jual beli yang dilakukan akan batal menurut prinsip syariah.

Bank syariah yang ada di Negara Kesatuan Republik Indonesia belum murni melaksanakan syariat islam sepenuhnya sebagaimana menurut ulama' dari 10 Provinsi di Indonesia. Implementasi akad murabahah yang dilakukan bank syariah jelas telah melanggar prinsip-prinsip syariah yang diatur oleh DSN-MUI (Haitam, 2015). Berdasarkan kondisi ini maka diperlukan penelitian lebih lanjut mengenai implementasi akad murabahah yang ada di lembaga Baitul Mal wa Tamwil yang ada di Indonesia.

Saat ini semakin banyak lembaga keuangan syariah, khususnya BMT, yang memberikan akses kemudahan manusia dalam kegiatan jual. Hal ini disebabkan oleh lembaga keuangan syariah yang memfasilitasi akses khusus bagi calon pengguna dalam memperoleh pembiayaan guna keperluan usaha. Dalam hal ini tentu dengan adanya tambahan biaya diluar pokok pembiayaan yang biasanya berupa bunga (interest). Kegiatan ini tentu saja tidak sesuai dengan prinsip syariat sebab interest termasuk kegiatan yang diharamkan oleh Allah SWT.

Dewasa ini, lembaga keuangan syariah telah memiliki peran aktif dalam perkembangan masyarakat dalam hal kebutuhan produksi yang membutuhkan modal besar. Lembaga keuangan syariah menjadi tulang punggung bagi para pelaku ekonomi guna mencari tambahan modal melalui mekanisme hutang dan tabungan. Lembaga keuangan syariah punya peran besar dalam pendistribusian sumber daya ekonomi di masyarakat (Shobirin,2016).

Dalam penelitian Haryoso (2017) bahwa pembiayaan murabahah di kabupaten Semarang sudah sesuai dengan prinsip syariah DSN-MUI tapi terdapat kekurangan yang 


\section{Al-Kharaj: Jurnal Ekonomi, Kenangan \& Bisnis Syariah \\ Volume 4 No 4 (2022) 1090-1106 P-ISSN 2656-2871 E-ISSN 2656-4351 DOI: $10.47467 /$ alkharaj.v4i4.840}

tidak sesuai dengan prinsip dari pihak nasabah yaitu para nasabah merasa bahwa pembiayaan murabahah yang diberikan oleh BMT Bina Usaha di Semarang masih kurang maksimal sebenarnya dikarenakan nasabah kurang memahami pembiayaan murabahah.

Penelitian Rochmaniah (2021) menjelaskan bahwa permasalahan yang terjadi pada pembiayaan murabahah berasal dari nasabah yang kurang memahami bagaimana pembiayaan murabahah yang dijalankan oleh KSPPS. Kesimpulannya bahwa akad murabahah yang dijalankan oleh BMT di Indonesia sudah sesuai dengan fatwa yang berlaku tetapi yang menjadi kendala terdapat pada nasabah yang kurang memahami pembiayaan saat penandatangan perjanjian sehingga nasabah merasa pembiayaan murabahah kurang tepat.

Hubungan antar sesama manusia, dibahas sebagaimana dalam ilmu fiqih, hubungan antara dua pihak yang bertransaksi dengan akad murabahah berarti mengikatkan antar pihak untuk bertransaksi sesuai dengan prinsip syariat islam. Dalam lembaga Baitul Mal Wa Tamwil, akad murabahah menjadi salah satu akad utama yang menyediakan kebutuhan pembiayaan bagi nasabah (Baidhowi, 2017)

Studi ini menggunakan lokasi penelitian pada BMT Masjid Raya Pondok Indah Jakarta. BMT Masjid Raya Pondok Indah Jakarta berdiri pada tahun 2002 yang tidak berada dibawah naungan koperasi maupun otoritas keuangan. Pada tahun 2019 terjadi perubahan sistem untuk seluruh BMT di Indonesia, untuk memilih tetap menggunakan BMT atau KSPPS.

BMT Masjid Raya Pondok Indah Jakarta merubah nama menjadi KSPPS Usaha Mulya yang dinaungi oleh koperasi. KSPPS merupakan koperasi sebagai sarana memberdayakan perekonomian umat melalui Kerjasama antara pihak KSPPS dengan masyarakat dalam bentuk pembiayaan, layanan konsumtif, dan layanan syariah lainnya. Dalam hal penggalian informasi terkait penelitian ini, peneliti melakukan wawancara kepada salah satu pihak BMT Masjid Raya Pondok Indah Jakarta yang sekaligus menjadi pengurus.

Tabel 1 Daftar Informan

\begin{tabular}{|l|l|l|}
\hline Nama Informan & Jabatan & Keterangan \\
\hline Ika & Keuangan & Ketua keuangan \\
\hline
\end{tabular}

Dari permasalahan yang telah dijelaskan diatas, penulis dalam studi ini berusaha untuk melakukan penelitian dengan pendekatan kualitatif dan studi 


\section{A1-Kharaj: Jurnal Ekonomi, Kenangan E Bisnis Syariah \\ Volume 4 No 4 (2022) 1090-1106 P-ISSN 2656-2871 E-ISSN 2656-4351 DOI: $10.47467 /$ alkharaj.v4i4.840}

kasus yang bertujuan dalam melakukan analisis implementasi akad murabahah pada BMT Masjid Syariah Raya Pondok Indah Jakarta.

\section{METODE PENELITIAN}

Jenis penelitian yang digunakan dalam penelitian ini adalah penelitian kualitatif. Data yang diperoleh akan diuji dan dianalisis menggunakan analisis deskriptif.. Penelitian ini menggunakan studi kasus dengan subjek penelitian akad Murabahah. Penelitian dilakukan untuk menginvestigasi penerapan akad pembiayaan murabahah yang sesuai dengan prinsip Syariah di BMT Masjid Raya Pondok Indah Jakarta.

Sumber data penelitian menggunakan sumber data primer yang diperoleh dari seorang informan yaitu pengurus dari BMT Masjid Raya Pondok Indah Jakarta. Metode pengumpulan data yang digunakan dalam penelitian ini adalah dengan melakukan wawancara secara mendalam dengan pihak BMT Masjid Raya Pondok Indah Jakarta. Selain data primer, penelitian juga memperoleh data dari sumber data sekunder melalui studi literatur.

\section{HASIL DAN PEMBAHASAN}

Menurut ulama Hanafiyah menyatakan bahwa murabahah adalah memindahkan hak atas barang milik seseorang kepada pembeli sesuai dengan transaksi dan harga awal yang dilakukan pemilik awal ditambah dengan keuntungan (margin) yang diinginkan. Ulama Syafi'iyah dan Hanabilah menyebutkan bahawa murabahah adalah akad jual beli yang dilakukan penjual kepada pembeli dengan mendasarkan pada harga beli penjual ditambah keuntungan dengan syarat harus sepengetahuan kedua belah pihak. Adapun menurut Syaikh Prof. Dr. Wahbah Az Zuhaili, seorang ulama Suria, mendefinisikan mengenai akad murabahah adalah sebagai akad jual beli yang dilakukan penjual kepada pembeli dengan harga awal ditambah dengan keuntungan. Penjual menyampaikan harga beli atas perolehan barang tersebut kepada pembeli ditambah dengan permintaan keuntungan yang dikehendaki penjual kepada pembeli.

Setiap akad pembiayaan yang diterapkan oleh bank syariah tentunya mempunyai suatu dasar yang kuat untuk dapat melaksanakan hal tersebut. Berikut ini adalah dasar hukum yang digunakan oleh Dewan Syariah Nasional dalam pelaksanaan pembiayaan murabahah:

Artinya: "Mengenai riba yaitu orang - orang yang makan (mengambil) riba tidak dapat berdiri melainkan seperti berdirinya orang yang kemasukan syaitan lantaran (tekanan) penyakit gila, keadaan mereka yang demikian itu adalah disebabkan mereka berkata,jual beli sama dengan riba, padahal Allah telah menghalalkan jual beli dan mengharamkan riba, orang - orang yang telah sampai padanya larangan dari tuhannya lalu terus berhenti (dari mengambil riba), maka baginya apa yang telah diambilnya dahulu (sebelum datang larangan) dan urusannya (terserah) kepada Allah, orang yang 


\section{Al-Kharaj: Jurnal Ekonomi, Kenangan \& Bisnis Syariah \\ Volume 4 No 4 (2022) 1090-1106 P-ISSN 2656-2871 E-ISSN 2656-4351 \\ DOI: 10.47467/alkharaj.v4i4.840}

kembali (mengambil riba) maka orang itu adalah penghuni neraka, mereka kekal di dalamnya". (QS.al-Baqarah (2):275)

Artinya: "Hai Orang-orang yang beriman, jika kamu orang-orang yang beriman, penuhi kewajibanmu kepada Allah dan tinggalkan sisa riba. Tetapi jika Anda tidak bekerja (dan meninggalkan sisa riba), Kamu tahu bahwa Allah dan rasul-Nya akan memerangi Anda. Dan jika kamu bertaubat (dengan riba), pokok hartamu adalah bagimu. Kamu tidak dianiaya dan tidak (lagi) dianiaya". (QS Al- Baqarah: 278-279)

Artinya: "Jauhi tujuh hal yang membinasakan! Para sahabat berkata, "Wahai, Rasulullah! apakah itu? Beliau bersabda, "Syirik kepada Allah, sihir, membunuh jiwa yang diharamkan Allah tanpa haq, memakan harta riba, memakan harta anak yatim, lari dari medan perang dan menuduh wanita beriman yang Ialai berzina" (Muttafaq 'alaih).

Akad murabahah sebagai sarana pembiayaan bagi lembaga keuangan syariah memiliki aturan terkait implementasinya agar transaksi yang akan dilakukan tidak bertentangan dengan syariat islam. Sebagaimana dalam fatwa DSN-MUI No. 111/DSNMUI/IX/2017 tentang Akad Jual Beli Murabahah, yaitu barang yang ditransaksikan tergolong barang/jasa halal sesuai syariat islam, lembaga BMT dapat melakukan pembiayaan sebagian atau seluruhnya dari harga pokok pembelian barang yang telah disepakati antara pihak.

Kedua, lembaga BMT melakukan transaksi pembelian barang/jasa yang dibutuhkan nasabah atas nama lembaga BMT sendiri dan sesuai syariat islam. Ketiga, lembaga BMT diharuskan menyampaikan semua informasi yang berhubungan dengan pembelian barang/jasa dan tidak ada yang bersifat rahasia.

Selanjutnya, lembaga BMT menjualkan barang/jasa tersebut kepada pemesan dengan harga pokok penjualan senilai harga beli BMT dari penyedia barang/jasa ditambah proporsi keuntungan yang diharapkan lembaga BMT. Namun, apabila lembaga BMT bersifat mewakilkan (murabahah bil wakalah) kepada pemesan untuk membeli barang/jasa dari pihak ketiga, akad jual beli atas transaksi yang dilakukan setelah barang didapatkan dari pihak penyedia, maka prinsip pengakuan barang dari penyedia menjadi milik lembaga BMT, dan lembaga BMT dapat memberikan perjanjian atas barang jaminan yang akan diserahkan agar pemesan serius dengan pesanannya.

Jika dilihat dari rukun, terdapat beberapa rukun, yaitu penjual, pembeli, barang, harga jual, dan Ijab qabul. Sedangkan, untuk syarat dibagi menjadi 4 bagian, yaitu syarat untuk pihak yang berakad atau penjual dan pembeli, objek yang diperjual belikan, syarat ijab qabul, dan syarat untuk harga. Syarat untuk penjual dan pembeli terdiri atas cakap hukum dan sukarela, tidak dalam kondisi terpaksa.

Syarat untuk objek yang diperjual belikan antara lain adalah produk/barang harus halal, bukan barang yang dilarang atau diharamkan oleh syariah Barang dagangan harus bermanfaat, produk/barang merupakan hak milik penuh pihak yang berakad, produk/barang sesuai spesifikasi dan kualifikasi yang diserahkan penjual kepada 


\section{Al-Kharaj: Jurnal Ekonomi, Kenangan \& Bisnis Syariah \\ Volume 4 No 4 (2022) 1090-1106 P-ISSN 2656-2871 E-ISSN 2656-4351 \\ DOI: $10.47467 /$ alkharaj.v4i4.840}

pembeli, jika barang bergerak harus dikuasai pembeli setelah dokumentasi dan perjanjian akad selesai, produk/barang harus jelas kualitas dan kuantitasnya, dan harga barang harus jelas.

Syarat untuk ijab-qabul diantaranya disebutkan secara rinci siapa saja pihak yang terlibat di dalam akad jual beli, serah terima produk/barang harus sebanding dengan harga yang telah disepakati, dan tidak membatasi waktu. Terakhir, syarat untuk harga antara lain harga jual adalah harga perolehan ditambah dengan keuntungan (margin), harga jual dalam bentuk tetap atau tidak berubah selama masa perjanjian dan sistem pembayaran dan jangka waktu harus disepakati bersama.

Murabahah dibagi menjadi dua jenisnya, yaitu Murabahah berdasarkan pesanan dan Murabahah tanpa pesanan. Murabahah berdasarkan pesanan yaitu penjual membeli produk/barang jika ada pesanan dari pembeli yang sifatnya mengikat atau tidak mengikat pembeli untuk membeli produk yang dipesan tersebut.

Murabahah yang bersifat mengikat berarti pesanan tersebut tidak diperbolehkan dibatalkan atau pembeli harus membeli barang tersebut. Sedangkan murabahah yang bersifat tidak mengikat adalah pembeli dapat menerima atau membatalkan barang pesanan tersebut. Sedangkan, Murabahah tanpa pesanan yaitu murabahah yang tidak mengikat yang di dalam penerapannya penyedia barang dilakukan sendiri oleh penjual.

Murabahah memiliki berbagai keunggulan daripada akad yang lain. Keunggulankeunggulannya tersebut antara lain adalah murabahah adalah suatu mekanisme investasi jangka pendek yang cukup memudahkan. Selain itu, keuntungan dalam murabahah dapat ditetapkan perbankan syariah sedemikian rupa sehingga memastikan bahwa bank syariah dapat memperoleh keuntungan yang sebanding dengan keuntungan bank umum yang berbasis bunga. Keunggulan yang terkhir adalah murabahah mampu menjauhkan ketidakpastian dibandingkan dengan sistem profit and loss sharing (PLS)

Akad Murabahah tak terlepas dari risiko-risiko seperti risiko terkait dengan barang, dan risiko terkait dengan nasabah dan pembayarannya. Bank syariah membeli barang yang diminta atau dipesan oleh nasabah, tentu saja bank harus menanggung risiko jika ada kehilangan dan kerusakan pada barang-barang tersebut dari saat pembelian sampai diserahkan kepada nasabah. Dengan akad murabahah bank wajib menyerahkan barang dalam kondisi baik kepada nasabah. Kemudian nasabah mempunyai hak untuk menolak barang-barang yang apabila mengalami kerusakan, kurang jumlahnya, dan tidak sesuai dengan spesifikasi dan kualifikasinya. Risiko selanjutnya adalah adanya penolakan dari nasabah atas barang tersebut.

Dalam untuk menghindari risiko nasabah tersebut adalah dengan mewajibkan kepada nasabah untuk melakukan pembayaran uang muka dan dengan jaminan. Risiko yang lain adalah risiko tidak terbayar penuh seperti yang telah dijadwalkan dalam surat perjanjian/kontrak. Untuk mengatasinya, pihak bank syariah membuat perjanjian tertulis, meminta jaminan, jaminan pihak ketiga, dan ketentuan tersendiri dari kontrak 


\section{Al-Kharaj: Jurnal Ekonomi, Kenangan \& Bisnis Syariah \\ Volume 4 No 4 (2022) 1090-1106 P-ISSN 2656-2871 E-ISSN 2656-4351 DOI: $10.47467 /$ alkharaj.v4i4.840}

yang menyatakan bahwa semua hasil dari barang- barang murabahah yang dijual kepada pihak ketiga dengan tunai maupun tidak tunai harus di taruh di bank sampai apa yang menjadi hak bank dibayar sepenuhnya.

Implementasi akad murabahah pada lembaga keuangan syariah, khususnya BMT, masih perlu ditingkatkan kembali atas akad murabahah yang telah terlaksana. Dalam hal ini, peneliti memaparkan tentang hasil wawancara dengan pihak BMT Masjid Raya Pondok Indah Jakarta. Kemudian yang menjadi pokok pembahasan disini adalah peneliti melakukan eksplorasi terkait penerapan akad murabahah yang digunakan BMT Masjid Raya Pondok Indah Jakarta dalam pembiayaan dengan akad murabahah. Selanjutnya peneliti mengemukakan delapan pertanyaan penting yang peneliti ajukan kepada pihak BMT Masjid Raya Pondok Indah Jakarta yang peneliti telah diuraikan pada bagian metode penelitian. Terakhir, terkait dengan temuan yang didapatkan peneliti adalah sebagai berikut:

BMT Masjid Raya Pondok Indah Jakarta melaksanakan akad terkait pembiayaan ada lima mekanisme. Dalam hal ini ada akad pembiayaan secara murabahah, ijarah, hiwalah, musyarakah dan mudharabah. Namun dari kelima mekanisme tersebut yang saat ini digunakan oleh BMT Masjid Raya Pondok Indah Jakarta dalam penerapan pembiayaan yakni akad murabahah, ijarah dan hiwalah. Hal ini sesuai yang dijelaskan oleh Ika pada pernyataan berikut:

“...Pembiayaan yang terdapat disini sih ada lima mbak, itu ada Murabahah, Ijarah, Hiwalah, Musyarakah, dan Mudharabah. Tapi untuk saat ini pembiayaan yang digunakan hanya tiga yaitu Murabahah, Ijarah, dan Hiwalah. Dari ketiga itu yang banyak digunakan murabahah murni dan murabahah wakalah. Murabahah murni hanya digunakan untuk pembiayaan motor saja selain itu menggunakan murabahah wakalah..." (Ika).

Lembaga keuangan syariah khususnya lembaga BMT saat ini memiliki banyak inovasi dan terobosan baru terkait dengan skema pembiayaan. Hal ini menjadikan masyarakat cenderung memilih BMT sebagai sarana pembiayaan karena sistem pembiayaan yang ditawarkan oleh BMT mudah dipahami oleh masyarakat. Pernyataan ini dikuatkan oleh pernyataan pihak BMT sebagai berikut:

“...Banyak sekali masyarakat atau pedagang yang ingin meminjam uang ke bank tapi gimana ya mba ngerti dengan sistem yang digunakan sehingga mereka lebih memilih meminjam uang kesini..." (Ika).

Skema pembiayaan yang dilakukan oleh BMT Masjid Raya Pondok Indah Jakarta seperti pada BMT umumnya. Alur pertama kali yakni nasabah mengisi form pengajuan aplikasi pembiayaan. Kemudian pihak BMT Masjid Raya Pondok Indah Jakarta melakukan survei ke tempat usaha nasabah dan tempat tinggal nasabah. Hal ini dilakukan sesuai dengan prinsip Know Your Customer sehingga BMT Masjid Raya Pondok Indah Jakarta mengetahui kebenaran dan keberadaan lokasi tempat usaha dan tempat tinggal nasabah bukan fiktif. Hal ini sesuai dengan pernyataan pihak BMT sebagai berikut: 


\section{Al-Kharaj: Jurnal Ekonomi, Kenangan E Bisnis Syariah Volume 4 No 4 (2022) 1090-1106 P-ISSN 2656-2871 E-ISSN 2656-4351 DOI: $10.47467 /$ alkharaj.v4i4.840}

“...alur pertama kali nasabah mengisi form pengajuan aplikasi pembiayaan tapi sebelum itu nasabah sudah harus mengetahui barang apa yang ingin dibeli dan downpayment yang dibutuhkan. Setelah itu pihak dari BMT akan melakukan survei tempat tinggal dan usaha. Selanjutnya akan diadakan rapat komite untuk memutuskan jumlah pinjaman yang dibolehkan sesuai dari hasil survei. Dari hasil rapat itu jika sudah disetujui maka dana dicairkan dalam waktu 2 minggu. Kalo nasabah dan pihak BMT sudah setuju ada beberapa administrasi yang harus dibayar yaitu administrasi dari Rp 7.000 - Rp 98.000 tergantung nominal pembiayaan sama notaris jika pembiayaan lebih dari Rp 20.000.000 dengan nominal Rp 120.000 ..." (Ika).=Jika alur skema pembiayaan murabahah BMT Masjid Raya Pondok Indah Jakarta dijelaskan dalam flowchart, maka flowchart alur skema pembiayaan sebagai berikut: 


\section{Al-Kharaj: Jurnal Ekonomi, Kenangan \& Bisuis Syariah}

Volume 4 No 4 (2022) 1090-1106 P-ISSN 2656-2871 E-ISSN 2656-4351

DOI: 10.47467/alkharaj.v4i4.840

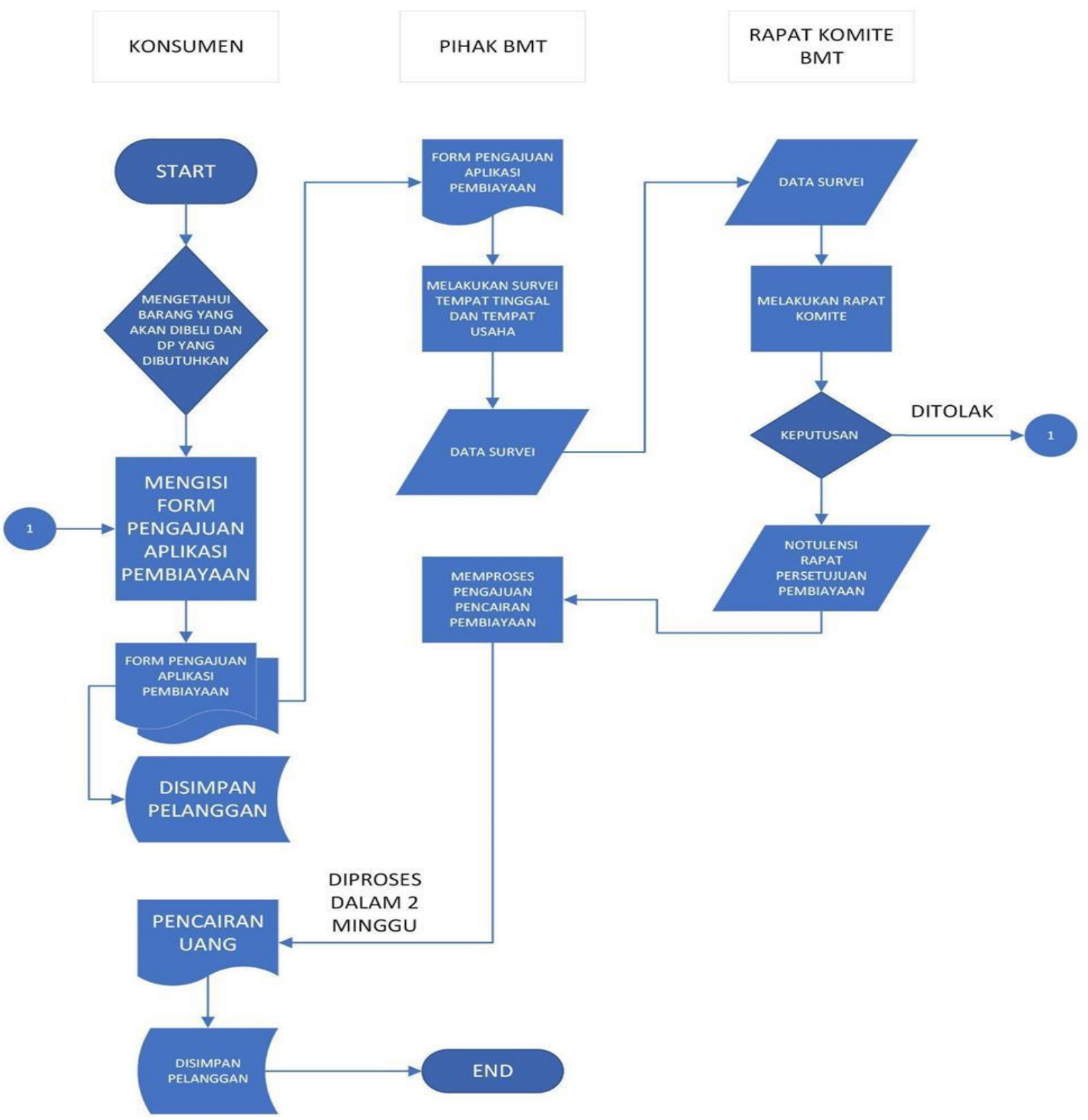




\section{Al-Kharaj: Jurual Ékonomi, Kenangan \& Bisnis Syariah \\ Volume 4 No 4 (2022) 1090-1102 P-ISSN 2656-2871 E-ISSN 2656-4351 \\ DOI: $10.47467 /$ alkharaj.v4i4.840}

Nasabah BMT Masjid Raya Pondok Indah Jakarta wajib mengetahui barang apa yang akan dibeli dan biaya yang diperlukan setelah itu nasabah baru dapat melakukan pembiayaan murabahah. Proses pembayaran pembiayaan dapat dipilih oleh nasabah sesuai dengan kenyamanan. Dalam hal ini sebagaimana sesuai dengan pernyataan pihak BMT Masjid Raya Pondok Indah Jakarta sebagai berikut:

“...Untuk pembayaran setiap bulannya dibagi menjadi tiga ada jemput bola atau bagian penagihan akan mengontak nasabah setelah itu nasabah baru akan membayar. Terus yang kedua nasabah datang langsung ke BMT, dan yang ketiga nasabah dapat mentransfer pembayaran ke bank muamalat atau sistem pembayaran langsung terdebet dari bank nasabah..." (Ika).

BMT Masjid Raya Pondok Indah Jakarta dalam penentuan margin sesuai dengan jenis produk yang dibeli dan jumlah pembiayaan yang terlaksana. Hal ini sesuai dengan pernyataan pihak BMT Masjid Raya Pondok Indah Jakarta sebagai berikut:

“...Margin murabahah disini ada tiga jenis tergantung jenis barang dan nominal pembiayaan yang pertama sebesar $1 \%$ per bulan khusus motor dengan semua harga, margin motor khusus karena bersaing dengan dealer. Yang kedua pembiayaan lebih dari Rp 15.000.000 marginnya 2\% perbulan dan yang ketiga pembiayaan kurang dari Rp 15.000.000 marginnya $2.5 \%$..." (Ika).

Adapun terkait dengan kepemilikan barang pembiayaan, BMT Masjid Raya Pondok Indah Jakarta menggunakan prinsip perwakilan (wakalah) sehingga tidak ada satupun barang pembiayaan yang dilaksanakan BMT Masjid Raya Pondok Indah Jakarta yang diakui sebagai barang milik BMT Masjid Raya Pondok Indah Jakarta. Hal ini sesuai dengan pernyataan pihak BMT Masjid Raya Pondok Indah Jakarta sebagai berikut:

“...Kepemilikan barang yang dibeli atas nama nasabah itu sendiri jadi tidak ada atas nama BMT tapi untuk motor walaupun atas nama nasabah tapi BPKB motor harus diserahkan ke pihak BMT sebagai jaminan sampai nasabah dapat melunasi pembiayaan..." (Ika).

BMT Masjid Raya Pondok Indah Jakarta memastikan bahwa nasabah sebelum mendaftarkan pembiayaan, nasabah disarankan untuk mensurvei barang dan harga terlebih dahulu. Apabila nasabah tidak sanggup untuk membayar sisa pembiayaan maka nasabah dapat mengajukan kepada BMT Masjid Raya Pondok Indah Jakarta. Hal ini sesuai dengan pernyataan yang disampaikan oleh pihak BMT Masjid Raya Pondok Indah Jakarta sebagai berikut:

“...Nasabah sebelum mendaftarkan pembiayaan lebih dulu mensurvei barang dan harga setelah itu nasabah mengajukan sisa ketidaksanggupan biaya ke BMT. Contohnya seperti ini 


\section{Al-Kharaj: Jurual Ekonomi, Kenangan \& Bisnis Syariah \\ Volume 4 No 4 (2022) 1090-1102 P-ISSN 2656-2871 E-ISSN 2656-4351 \\ DOI: $10.47467 /$ alkharaj.v4i4.840}

misalnya nasabah ingin membeli motor seharga Rp 20.000.000 tapi nasabah cuma punya uang $\mathrm{Rp} 4.000 .000$, berarti kan masih kurang Rp 16.000.000, nominal itu yang diajukan. Untuk mengajukan itu nasabah membawa bukti pembelian dengan harga motornya..." (Ika).

BMT Masjid Raya Pondok Indah Jakarta dalam proses pembiayaan yang telah dilaksanakan, BMT Masjid Raya Pondok Indah Jakarta mengalami beberapa kendala terkait dengan kekurangan personel dan kekurangan tempat dalam melakukan transaksi murabahah baik murni maupun campuran. Hal ini sesuai dengan pernyataan pihak BMT Masjid Raya Pondok Indah Jakarta sebagai berikut:

“...Sebetulnya kendala dari kita saat ini kekurangan pegawai jadi satu orang dapat ngerjain dua pekerjaan terus kita nggak bisa gunai murabahah murni karena nggak punya tempat untuk penyimpanan barang. Kendala dari nasabah mungkin karena sedang pandemi jadi mungkin agak kesulitan untuk membayar tapi sampai saat ini enggak ada yang tidak dapat membayar sama sekali..." (Ika).

Penjelasan diatas adalah hasil penemuan dari studi yang dilakukan kepada BMT Masjid Raya Pondok Indah Jakarta. Berdasarkan hasil wawancara tersebut bahwa BMT Masjid Raya Pondok Indah Jakarta telah menjalankan dan menerapkan kegiatan pembiayaan khususnya terkait dengan pembiayaan murabahah dengan mengacu pada prinsip-prinsip syariah islam yang berlaku. Dalam penemuan ini bisa diketahui mengenai proses pembiayaan terhadap nasabah. Namun, yang masih menjadi kendala dalam BMT Masjid Raya Pondok Indah Jakarta untuk mengimplementasikan akad murabahah adalah terkait dengan kekurangan personel dan kekurangan tempat sehingga proses implementasi akad murabahah yang diterapkan pada BMT Masjid Raya Pondok Indah Jakarta menjadi kurang maksimal.

Tabel 2 Implementasi Pembiayaan Murabahah pada BMT dengan Fatwa MUI

\begin{tabular}{|l|l|l|}
\hline $\begin{array}{l}\text { Fatwa DSN-MUI } \\
\text { No. 111/DSN-MUI/IX/2017 }\end{array}$ & $\begin{array}{l}\text { Simpula } \\
\text { pada BMT Masjid Raya } \\
\text { Pondok Indah Jakarta }\end{array}$ & n \\
\hline $\begin{array}{l}\text { Barang yang ditransaksikan } \\
\text { tergolong barang/jasa halal } \\
\text { sesuai syariat islam. }\end{array}$ & $\begin{array}{l}\text { Barang yang paling banyak } \\
\text { diajukan oleh nasabah pada } \\
\text { pembiayaan murabahah } \\
\text { berupa peralatan dan } \\
\text { perlengkapan usaha } \\
\text { seperti alat }\end{array}$ \\
\hline
\end{tabular}




\section{A1-Kharaj: Jurual Ekonomini, Kenangan ₹ Bisnis Syariah}

\section{Volume 4 No 4 (2022) 1090-1102 P-ISSN 2656-2871 E-ISSN 2656-4351}

DOI: 10.47467 /alkharai.v4i4.840

\begin{tabular}{|c|c|c|}
\hline & $\begin{array}{l}\text { masak, tempat untuk } \\
\text { jualan, } \quad \text { motor, dan } \\
\text { handphone. }\end{array}$ & \\
\hline $\begin{array}{llr}\text { Melakukan } & \text { pembiayaan } \\
\text { sebagian } & \text { atau } & \text { seluruhnya } \\
\text { dari } & \text { harga } & \text { pokok } \\
\text { pembelian } & \text { barang } & \text { yang } \\
\text { telah } & \text { disepakati } & \text { antara } \\
\text { pihak. } & & \end{array}$ & 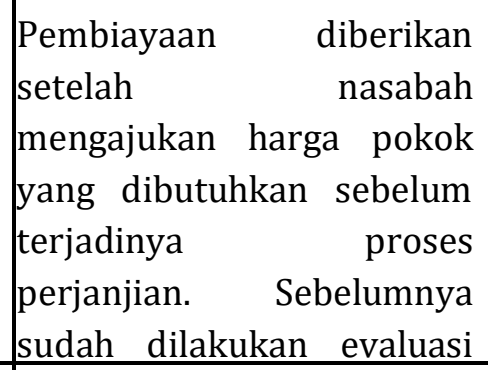 & Sesuai \\
\hline $\begin{array}{l}\text { Transaksi } r \text { pembelian } \\
\text { barang/jasa } \\
\text { dibutuhkan nasabah atas } \\
\text { nama lembaga BMT sendiri } \\
\text { dan sesuai syariat islam. }\end{array}$ & $\begin{array}{l}\text { Barang yang sudah dibeli } \\
\text { tidak ada atas nama BMT } \\
\text { Masjid Raya Pondok Indah } \\
\text { Jakarta. Seperti motor } \\
\text { diatasnamakan nasabah itu } \\
\text { sendiri dengan jaminan } \\
\text { Bukti Pemilikan Kendaraan } \\
\text { Bermotor (BPKB) motor }\end{array}$ & $\begin{array}{l}\text { Tidak } \\
\text { Sesuai }\end{array}$ \\
\hline 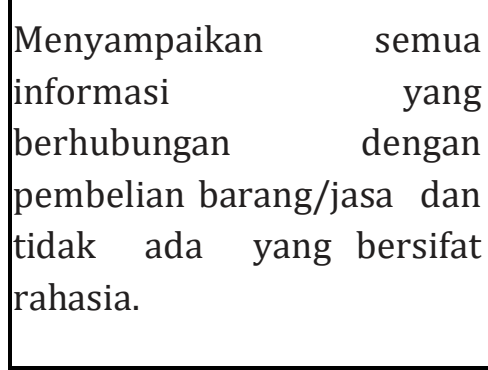 & \begin{tabular}{|lrr} 
Sebelum & terjadinya \\
pembiayaan, & nasabah akan \\
diberikan & penjelasan \\
mengenai & pembiayaan \\
murabahah & dari & margin \\
yang & akan & diberikan \\
setiap & bulannyar & Serta \\
\end{tabular} & Sesuai \\
\hline
\end{tabular}




\section{A1-Kharaj: Jurual Ékonomi, Kenangan \& Bisuis Syariah \\ Volume 4 No 4 (2022) 1090-1102 P-ISSN 2656-2871 E-ISSN 2656-4351 \\ DOI: $10.47467 /$ alkharaj.v4i4.840}

\begin{tabular}{|c|c|c|}
\hline $\begin{array}{l}\text { Memberikan perjanjian } \\
\text { atas barang jaminan yang } \\
\text { akan diserahkan agar } \\
\text { pemesan serius dengan } \\
\text { pesanannya. }\end{array}$ & $\begin{array}{lrr}\text { Setiap pembiayaan } & \text { akan } \\
\text { diajukan } & \text { terdapat } \\
\text { beberapa } & \text { syarat } & \text { dan } \\
\text { jaminan } & \text { seperti } & \text { Bukti } \\
\text { Pemilikan } & \text { Kendaraan } \\
\text { Bermotor } & \text { (BPKB) } & \text { untuk } \\
\text { motor dan } & \text { Sertifikat tanah } \\
\text { serta } & \text { Pajak } & \text { Bumi } \\
\text { Bangunan } & \text { (PBB) bagi yang } \\
\text { meminjam untuk renovasi } \\
\text { rumah atau tempat usaha. } \\
\text { Jaminan ini berlaku untuk } \\
\text { pembiayaan diatas Rp } \\
\text { 1.500.000 }\end{array}$ & Sesuai \\
\hline $\begin{array}{l}\text { Lembaga BMT bersifat } \\
\text { mewakilkan (murabahah } \\
\text { bil wakalah) kepada } \\
\text { pemesan untuk membeli } \\
\text { barang/jasa dari pihak } \\
\text { ketiga, akad jual beli atas } \\
\text { transaksi yang dilakukan } \\
\text { setelah barang didapatkan } \\
\text { dari pihak penyedia, maka } \\
\text { prinsip pengakuan barang } \\
\text { dari penyedia menjadi } \\
\text { milik lembaga BMT. }\end{array}$ & $\begin{array}{l}\text { BMT Masjid Raya Pondok } \\
\text { Indah Jakarta akan } \\
\text { memberikan pembiayaan } \\
\text { ke nasabah setelah } \\
\text { perjanjian antara kedua } \\
\text { pihak sudah disepakati. } \\
\text { Setelah itu nasabah akan } \\
\text { memberikan bukti atas } \\
\text { pembelian barang kepada } \\
\text { pihak BMT Masjid Raya } \\
\text { Pondok Indah Jakarta. } \\
\text { Barang yang dibeli oleh } \\
\text { nasabah akan } \\
\text { diatasnamakan nasabah } \\
\text { itu sendiri untuk } \\
\text { menghindari kesulitan } \\
\text { perubahan nama pada } \\
\text { barang di akhir masa } \\
\text { pembiayaan. }\end{array}$ & $\begin{array}{l}\text { Tidak } \\
\text { Sesuai }\end{array}$ \\
\hline
\end{tabular}




\section{A1-Kharaj: Jurval Ekonomi, Kenangan है Bisnis Syariah \\ Volume 4 No 4 (2022) 1090-1102 P-ISSN 2656-2871 E-ISSN 2656-4351 DOI: 10.47467 /alkharai.v4i4.840}

Berdasarkan pada tabel 2 perbandingan atas implementasi fatwa MUI dengan implementasi akad murabahah yang diterapkan pada BMT Masjid Raya Pondok Indah Jakarta terdapat enam dasar pelaksanaan pembiayaan murabahah, dari keenam fatwa MUI terdapat empat hal yang sesuai dengan fatwa dan terdapat dua hal yang tidak sesuai. Implementasi BMT Masjid Raya Pondok Indah Jakarta yang sesuai terdapat pada Barang yang ditransaksikan tergolong barang atau jasa halal sesuai syariat islam, Melakukan pembiayaan sebagian atau seluruhnya dari harga pokok pembelian, memberikan informasi mengenai pembiayaan, dan terdapat penjanjian atas barang jaminan.

Implementasi yang tidak sesuai terdapat pada transaksi pembelian barang atau jasa yang dibutuhkan nasabah atas nama lembaga BMT Masjid Raya Pondok Indah Jakarta, disini pembelian barang atas nama nasabah untuk tidak mempersulit pengurusan ganti nama. Dan tidak sesuai kedua Lembaga BMT bersifat mewakilkan (murabahah bil wakalah) kepada pemesan untuk membeli barang/jasa dari pihak ketiga, akad jual beli atas transaksi yang dilakukan setelah barang didapatkan dari pihak penyedia, maka prinsip pengakuan barang dari penyedia menjadi milik lembaga BMT, pembiayaan yang digunakan sudah sesuai murabahah bil wakalah tapi implementasi atas pengakuan barang yang tidak sesuai.

Berdasarkan analisis diatas dapat disimpulkan bahwa BMT Usaha Mulya Pondok Indah Jakarta dalam implementasi akad murabahah yang diatur dalam Fatwa DSN-MUI No. 111/DSN- MUI/IX/2017 tentang Akad Jual Beli Murabahah, kesesuaian antara Fatwa DSN-MUI No. 111/DSN- MUI/IX/2017 dan mekanisme yang ada di BMT Usaha Mulya Pondok Indah Jakarta menunujukkan beberapa hal yang perlu diperhatikan sehingga pelaksanaan pembiayaan atas akad murabahah tidak melanggar kepada aturan syariah yang telah ditetapkan oleh Dewan Syariah Nasional Majelis Ulama Indonesia.

Tabel 3 Kendala dan Solusi Implementasi Pembiayaan Murabahah pada BMT Masjid Raya Pondok Indah Jakarta

\begin{tabular}{|l|l|}
\hline Kendala & \\
\hline
\end{tabular}




\section{Al-Kharaj: Jurual Ékonomi, Kenangan \& Bisnis Syariah \\ Volume 4 No 4 (2022) 1090-1102 P-ISSN 2656-2871 E-ISSN 2656-4351 DOI: $10.47467 /$ alkharaj.v4i4.840}

\begin{tabular}{|c|c|c|}
\hline $\begin{array}{l}\text { Tidak } \\
\text { mengimplementasikan } \\
\text { murabahah murni } \\
\text { kurangnya tempat } \\
\text { menyimpan barang. }\end{array}$ & $\begin{array}{r}\text { dapat } \\
\text { karena } \\
\text { untuk }\end{array}$ & $\begin{array}{l}\text { Pihak BMT Usaha Mulya Pondok } \\
\text { Indah Jakarta dapat menyewa } \\
\text { tempat untuk menyimpan } \\
\text { barang-barang yang berkaitan } \\
\text { dengan pembiayaan murabahah. } \\
\text { Barang yang disimpan untuk } \\
\text { menghemat tempat dapat dipilih } \\
\text { barang yang paling banyak } \\
\text { diajukan oleh nasabah sehingga } \\
\text { BMT Usaha Mulya Pondok Indah } \\
\text { Iakarta dapat melakukan }\end{array}$ \\
\hline
\end{tabular}

Berdasarkan tabel 3 diatas kendala yang dihadapi oleh BMT Usaha Mulya Pondok Indah Jakarta memiliki tempat untuk menyimpan barang sehingga pembiayaan murabahah murni tidak dapat diimplementasikan oleh karena itu BMT Usaha Mulya Pondok Indah Jakarta menggunakan murabahah wakalah. Dengan kendala tersebut pihak BMT Usaha Mulya Pondok Indah Jakarta dapat menyewa tempat untuk sementara dan barang yang disimpan sesuai dengan banyaknya barang yang dipesan oleh nasabah.

\section{KESIMPULAN}

Murabahah adalah proses akad jual beli yang memindahkan hak atas barang milik seseorang kepada pembeli sesuai dengan transaksi dan harga awal yang dilakukan pemilik awal ditambah dengan keuntungan (margin) yang diinginkan. Permasalahan yang berkembang terkait pembiayaan murabahah adalah adanya tambahan biaya diluar pokok pembiayaan yang biasanya berupa bunga (interest).

Berdasarkan penelitian yang telah dilakukan pada BMT Masjid Raya Pondok Indah Jakarta

ditemukan bahwa BMT Masjid Raya Pondok Indah Jakarta, secara keseluruhan, belum menerapkan kegiatan pembiayaan murabahah sesuai pada prinsip-prinsip syariah yang diatur oleh Dewan Syariah Nasional Majelis Ulama Indonesia. Dalam hal ini, Prinsip yang belum dijalankan oleh BMT yaitu pengakuan kepemilikan barang yang seharusnya atas nama BMT tetapi barang kepemilikan atas nama nasabah.

Selain itu, terdapat beberapa hal terkait dengan penerapan akad murabahah bagi pihak BMT Masjid Raya Pondok Indah Jakarta. Dalam hal ini bahwa BMT tidak dapat mengimplementasikan murabahah murni dikarenakan kurangnya akses tempat untuk menyimpan barang yang dimiliki sehingga pihak BMT dalam 


\section{Al-Kharaj: Jurnal Ekonomi, Kenangan \&ै Bisnis Syariah \\ Volume 4 No 4 (2022) 1090-1102 P-ISSN 2656-2871 E-ISSN 2656-4351 DOI: $10.47467 /$ alkharaj.v4i4.840}

menjalankan pembiayaan murabahah wakalah yang terdapat lembaga untuk mewakilkan pembelian nasabah.

Pembiayaan yang digunakan saat ini yaitu Murabahah, Ijarah, dan Hiwalah sudah cukup untuk keperluan nasabah. Dari awal BMT ini berdiri hingga saat ini, pembiayaan paling banyak digunakan oleh nasabah adalah murabahah. Dari hasil penelitian murabahah sudah banyak membantu masyarakat untuk memudahkan mereka yang ingin bertransaksi tapi tidak mengerti proses alur pembiayaan di bank dan juga untuk mendapatkan margin yang lebih kecil dibandingkan di bank. Oleh karena itu, BMT Masjid Raya Pondok Indah Jakarta sebaiknya tetap menjaga praktik pembiayaan murabahah yang sudah berjalan sesuai dengan peraturan yang ada dan tetap menjaga kualitas pembiayaan di BMT Masjid Raya Pondok Indah Jakarta kepada para nasabah.

Berdasarkan penjelasan diatas, sebaiknya BMT Masjid Raya Pondok Indah Jakarta dapat

memulai untuk melakukan pembenahan sejak dini untuk menerapkan hal-hal yang perlu disesuaikan dalam pelaksanaan akad murabahah terhadap fatwa yang telah diatur oleh Dewan Syariah Nasional No. 111/DSN-MUI/IX/2017 tentang Akad Jual Beli Murabahah. Selanjutnya diharapkan BMT Usaha Mulya Pondok Indah Jakarta melakukan penambahan personel dan tempat bagi barang pembiayaan sehingga nantinya dapat mengimplementasikan akad murabahah secara murni. Terakhir, bagi peneliti selanjutnya diharapkan untuk melakukan penelitian yang lebih luas terhadap seluruh lembaga BMT yang ada di daerah DKI Jakarta sehingga nanti dapat menginterpretasikan hasil penerapan akad murabahah yang telah dilaksanakan oleh seluruh BMT yang ada di DKI Jakarta apakah sudah menerapkan prinsip akad murabahah atau belum.

\section{DAFTAR PUSTAKA}

Alfiani, Mila. Anwar, Aan Zainul. Darwanto. 2021. Analisis Pembiayaan Murabahah pada BMT.

Jurnal Ekonomi \& Ekonomi Syariah Vol 1 No 2, Juni 2018 E-ISSN : 2599-3410 / PISSN :

4321-1234.

Baidhowi. 2017. Rekonstruksi Akad Murabahah Studi Akad Murabahah di BMT SM NU Pekalongan. Yudisia. Vol.8 No.2.

Dafik. 2021. Pengertian Akad Murabahah, Jenis, Keunggulan, Risiko, dan Mekanismenya. Diakses obligasi.co.id pada 4 Desember 2021 pukul 10.00

Dewan Syariah Nasional Majelis Ulama Indonesia. MUI. "Fatwa DSN-MUI No. 111/DSN- MUI/IX/2017 tentang Akad Jual Beli Murabahah. https://drive.google.com/file/d/1PJqKTaew1MoSsxlJpXnblz5x2DKhSlfq/view diakses pada 12 Desember 2021. 


\section{A1-Kharaj: Jurnal Ékonomi, Kenangan E Bisnis Syariah \\ Volume 4 No 4 (2022) 1090-1102 P-ISSN 2656-2871 E-ISSN 2656-4351 DOI: $10.47467 /$ alkharaj.v4i4.840}

Haitam, Ibnu. 2015. "Review Of The Theory And Parctice Of Islamic Banking In Indonesia". AICIF. Vol.1 No.1.

Harsoyo, Lukman. 2017. Penerapan Prinsip Pembiayaan Syariah (Murabahah) pada BMT Bina Usaha di Kabupaten Semarang. Jurnal Law and Justice. Vol. 2 No. 1 April 2017.

Masjid Raya Pondok Indah. 2019. Koperasi dan Pembiayaan Syariah. Diakses dari masjidrayapondokindah.com pada 6 Desember 2021 pukul 16.00 WIB.

OJK. 2017. Konsep Operasional Perbankan Syariah. Diakses dari ojk.go.id pada 10 Desember 2021 pukul 10.00 WIB.

Quran Kemenag. 2021. Al-Quran Surah Al-Baqarah. Diakses dari quran.kemenag.go.id pada 17 Desember 2021 pukul 09.00 WIB.

Rochmaniah, Siti Ayu. Oktafia, Renny. (2021). Implementasi Pembiayaan Akad Murabahah dalam Upaya Peningkatan UMKM di KSPPS Permata Barokah Jaya Kelurahan Pandaan. Jurnal Ilmiah Ekonomi Islam, 7(02), 2021, 1038-1047.

Shobirin. 2016. Penyelesaian Pembiayaan Murabahah Bermasalah di Baitul Mal Wa Tamwil (BMT). Iqtishadia. P-ISSN: 1979-0724, E-ISSN: 2502-3993 Vol. 9, No. 2, 2016, 398-420. 